\title{
The Scottish Deathscape in South Asia: Madras aNd CeYlon
}

\author{
John M. MacKenzie
}

University of Lancaster

\begin{abstract}
Imperial deaths were given the status of martyrdoms in the cause of what European contemporaries considered the advance of civilisation. In many cases burials stimulated the overblown architecture of commemoration discovered in many places in the Indian Ocean world. There could well have been at least 1,000 cemeteries and church graveyards in South Asia, as well as grandiloquent memorials in cathedrals and churches throughout the region. While there are many examples from the eighteenth century, these practices became particularly striking in the nineteenth, which was an era in which the obsession with data produced a plethora of directories of memorial inscriptions and related lives. Some of these were officially inspired while others were produced by undertakers and those fascinated by documentation. From these we learn about imperial lives, careers, localised origins, and social and familial contexts. However, both these directories and the memorials which they documented were much more than the sentimental appropriation of colonial space. They also reflected ethnic and religious diversity, becoming indicators of the 'four nations' as well as of the contrasting Christian denominations of the United Kingdom. This was perhaps particularly true of Scots, whose geographical, social and religious affiliations can be charted through many examples in the Madras Presidency of South India and of the colony of Ceylon. They help to demonstrate that a full understanding of ethnic diversities can be derived from the study of the 'deathscape' of the imperial world.
\end{abstract}

As anyone who has visited the two remarkable cemeteries in South Park Street, Kolkata knows, the commemoration of imperial death in South Asia could take grandiloquent forms. The most celebrated of these cemeteries was a general one for white residents (and 
some mixed-race Anglo-Indians) of the East India Company capital, opened in 1767 and including some Scots. ${ }^{1}$ The lesser known one, inaugurated in 1826, was specifically for Scots. In this way Scots asserted their distinctive ethnicity, a sense of separateness which has been re-emphasised in recent times by the project to restore and record the tombs and structures of this Caledonian graveyard, for which the records are kept in the city's St. Andrew's Church. ${ }^{2}$ The new cemetery and church's significance lay in what their construction said about the consolidated presence of Scots within the English East India Company's wider colonial community in India. While the corporation remained largely anglicised in nature - as befitted one of London's premier (and pre-British) chartered organisations - the development of a new Scottish space and religious building in the heart of the Company's metropolis in Asia represented a practical manifestation of the markedly British nature of its personnel and associated merchants. ${ }^{3}$

This diversification in the forms of European mortality, religiosity and memorialisation aligns to existing literatures and debates on how empires used the human fragility of its representatives to create architectures and cityscapes designed to embed and cement colonial authority and prestige. Yet as well as emphasising how the Scottish cemetery conformed to the conventional religious, architectural and monumental practices of colonial society, this article explores how a focus on Scots reveals the subtle differences and diversities within outwardly uniform British deathscapes in South Asia. The striking and somewhat overblown architecture of remembrance in these graveyards was surely intended to convey a number of messages about British imperial rule. These included the supposed grandeur of the project, the frequency and contemporary sense of the cruelty of deaths, martyrdoms in what for the British was the cause of commerce and later civilisation. To these ideological concerns could be added the aspiration to secure a material as well as spiritual immortality in the alien context of South Asia and the need perhaps to emulate the pre-colonial recording of elite deaths, particularly among Muslims, in notable structures. ${ }^{4}$ There may additionally have been a distancing effect, marking out

\footnotetext{
${ }^{1}$ Though quickly filled up, the lairs at South Park Street continued to be used until the 1830s and 1840s. For the cultural role of cemeteries in colonial ordering, see: Elizabeth Buettner, "Cemeteries, public memory and Raj nostalgia in postcolonial Britain and India," History and Memory, 18, 1 (2006), 5-42; Ashish Chadha, "Ambivalent heritage: Between affect and ideology in a colonial cemetery," Journal of Material Culture, 11, 3 (2006), 339-63.

${ }^{2}$ See http://www.scotscemeteryarchivekolkata.com/ [accessed: 24 Aug. 2020].

${ }^{3}$ The noticeably more 'British-Irish' demography of the Company's main settlements compared to respective shares of population in the British and Irish Isles has been noted by historians of the eighteenth- and nineteenth-century phases of colonialism. See: P.J. Marshall, 'British society in India under the East India Company,” Modern Asian Studies, 31, 1 (1997), 90-1.

${ }^{4}$ Robert Travers, "Death and the Nabob: Imperialism and commemoration in eighteenth-century India," Past and Present, 196, 1 (2007), 83-124.
} 
the British from the demographic environment of India, with its very different Hindu disposal of the dead. Moreover, in the words of David Arnold, such self-regarding entombments could also be seen as 'the sentimental annexation of India,' in other words the laying down of powerful emotional markers. ${ }^{5}$ These dynamics point to the underexplored theme of religious identification in shaping the cultural assumptions, material practices and representational conventions of the colonial community in South Asia. How Scots expressed religious, professional and familial allegiances points to the less than monolithic nature of the colonising community, especially when compared with the unifying influence of ideas relating to civilising missions and racial commonalities. The ways in which Scotland's institutionally and theologically separate religious traditions diversified and complicated developments in British colonial settings are still largely associated with settler societies. ${ }^{6}$ A key aim of this article is to explore the possible lineaments of a Scottish deathscape in the very different settings of the East India Company's colonial presence in South Asia.

Death was of course an ever-present reality for the British in India until improvements in the understanding of bacteriology and medical developments in the twentieth century. The British Association for Cemeteries in South Asia (BACSA) has estimated that there are 1,000 British cemeteries and graveyards in the region and that there are some two million European burials in India and adjacent countries. ${ }^{7}$ The latter statistic is impossible to verify given the number of burials on roadsides and on battle sites. Wilkinson writes of the high mortality among groups of young writers sailing to India in the eighteenth century, each cohort often leaving only one or two survivors. ${ }^{8}$ Life expectancy was low for men, lower for women, and at its lowest for children. In view of this awareness and fear of death in the subcontinent, it is perhaps not surprising that Maria Callcott, sadly passing a burial ground in Calcutta 1810, wrote in her journal that 'it seems more sad to die in a foreign land than at home. ${ }^{9}$ She also commented, very accurately, on the remarkable speed with which the graveyards filled up.

\footnotetext{
${ }^{5}$ David Arnold, "Deathscapes: India in an age of romanticism and empire, 1800-1856," Nineteenth-Century Contexts, 26, 4 (2004), 345. See also: David Arnold, "The Indian Ocean as a disease zone, 1500-1950," South Asia: Journal of South Asian Studies, 14, 2 (1991), 1-21. I have taken his usage of 'deathscape' as the title for this article.

${ }^{6}$ Valerie Wallace, Scottish Presbyterianism and Settler Colonial Politics (Edinburgh: Edinburgh University Press, 2018), $2-4,8,19$.

${ }^{7}$ www.bacsa.org.uk [Accessed: 6 Dec. 2021]. The early cemeteries included Anglo-Indians.

${ }^{8}$ Theon Wilkinson, Two Monsoons: The life and death of Europeans in India (London: Duckworth, 1987), 6.

${ }^{9}$ Quoted in: Patrick Wheeler, Ribbons Among the Rajahs: A history of British women in India before the Raj (Barnsley: Pen and Sword, 2017), 224.
} 
Despite the plethora of cemeteries, these were not the only symptoms of imperial approaches to apparently heroic mortality. Considering the value of the Scottish dimensions of this wider phenomenon can begin by noting the increasingly complex forms and variable artistic genres of this socio-religious infrastructure of memorialisation. In addition to some impressive tombs and stones, there were grand memorials in cathedrals and churches, some of them represented by striking and often high-quality sculptures supplied by the leading sculptors of the day. These are among the finest to be seen anywhere in the Anglophone world outside Westminster Abbey and often represent an extraordinary trade from Europe to South Asia. ${ }^{10}$ Such memorials in ecclesiastical buildings were more likely to survive the environmental conditions of India and other colonies, and could be cherished in ways not always possible in cemeteries. Statues of an administrative, military and religious elite on the other hand were more likely to be attacked by the ravages of natural conditions and, even more so, by postcolonial political change and a public sense of the inappropriateness of their visibility in a decolonised world. ${ }^{11}$ Yet beyond all that, there was another way in which imperial deaths were recorded, in an extraordinary sequence of publications of a 'plethora of directories' of tomb inscriptions, sometimes supported by potted biographies of subjects, a seemingly endless 'discourse of exemplariness. ${ }^{12}$ These collected transcriptions seem to have become a passion in nineteenth-century India, one which took on an official form later in the century carrying over into the twentieth. Many of them have been republished in modern times because of their value to genealogists. The first example of this was compiled as Asiaticus in Two Parts, Ecclesiastical, Christian and Historical Sketches Respecting Bengal, published by John Hawkesworth in 1803 at the Hircarrah Press in Calcutta. ${ }^{13}$ This was followed by M. Derozario's The Complete Monumental Register Containing all the Epitaphs and Inscriptions....in and about Calcutta.... [with some from

\footnotetext{
${ }^{10}$ Excellent examples are to be found in St. Thomas's Cathedral, Bombay (Mumbai) and St. George's Cathedral, Madras (Chennai). See also: Anila Verghese, "Jonathan Duncan's Memorial in St. Thomas Cathedral, Mumbai," Journal of Asian Studies, 15, 1 (1999), 103-7. Duncan, Governor of Bombay 1795-1811 when he died in office, was born at Wardhouse, County of Forfar.

${ }^{11}$ One of the rare survivals is the equestrian statue by Sir Francis Chantrey of Sir Thomas Munro (1761-1827), son of a Glasgow tobacco merchant and Governor of Madras. It stands in the middle of a major road in the city and may have been left through sheer inertia, the cost of removal, or because of his sympathetic ryotwari system of taxation.

${ }^{12}$ These phrases come from: Trev Lynn Broughton, "The Bengal Obit: Reading and writing Calcutta graves in the midnineteenth century," Journal of Victorian Culture, 15, 1 (2010), 39-59. See also: Buettner, "Cemeteries, public memory and Raj nostalgia," 5-42. Buettner uses the statistic of two million deaths, perhaps from the same source.

${ }^{13}$ John Hawkesworth, Asiaticus in Two Parts, Ecclesiastical, Christian and Historical Sketches Respecting Bengal (Calcutta: Telegraph Press, 1803). It is generally assumed that Asiaticus was in fact John Hawkesworth.
} 
the Presidencies of Madras, Bombay, Isle of France etc.], published in Calcutta in 1815. ${ }^{14}$ These compilations inaugurated a striking tradition of such publications, including William Urquhart's The Oriental Obituary, published in Madras in 1809/1810. The development of new modes of memorialisation, not least through printed surveys, can be dated to the decades of the early- to mid- Company Raj (c1760-c.1820). This is an era when Scots were at their most numerous in the civil and military ranks and among the licensed free traders. At the same moment, civic, charitable and religious policies both projected the corporation's increasingly hegemonic status in India while exposing the Company to increasing challenges in the UK. ${ }^{15}$ Exploring memorialisation becomes a way of tracking these cross-currents of religious pluralism and the use of the demographic diversity of the British presence in India as a motif for naturalising the still consolidating Company state.

These increasingly elaborate productions of commemoration continued apace for the rest of the century. In 1848, a firm of undertakers, Holmes and Company, published The Bengal Obituary, containing no fewer than 5,100 inscriptions from tombs, graves and monuments to cover 'various parts of the Bengal and Agra Presidencies.' 16 This was clearly intended as a handbook to help mourners to choose appropriate epitaphs and sometimes poems, a seemingly endless record of eulogistic martyrdoms. This was not, however, a project restricted to Arnold's earlier 'Age of Romanticism.' As the century wore on, these directories of death, encyclopaedias of epitaphs came out in everincreasing numbers. In one, the compiler remarked that Portuguese gravestones and monuments in Ceylon had been broken up for use as ammunition in Dutch guns. Others had been used as foundations for a church, while the British had even used a memorial as a pig and horse trough. ${ }^{17}$ In reading them, one becomes aware of a near-hysterical awareness that tombs and monuments were fragile and likely to disappear, such that inscriptions had to be preserved in the more formal means of print on paper, though even

\footnotetext{
${ }^{14}$ This repeated some of the Asiaticus material and was reprinted in 2013. De Rozario may have been of the same family as Henry Derozio, celebrated poet and teacher at the Hindu College, who died of cholera at the age of 22 and is buried in South Park Street Cemetery.

${ }^{15}$ According to Cotton, editor of the later compilation, hardly any copies of Urquhart's work had survived, so print on paper could also have a fragile existence. For the Company's ambivalent relationship with church organisations in the British and Irish Isles, as well as its own religious provisions, see: Penelope Carson, The East India Company and Religion, 1698-1858 (London, 2012), 90-129.

${ }^{16}$ This was published (inevitably with a much longer title) by J. Thomas at the Baptist Mission Press in 1848, reprinted in 1851, with a modern edition in 1991. It is closely analysed in the Broughton article (Broughton, "The Bengal Obit," 39-59), fn 6.

${ }^{17} \mathrm{~J}$. Penry Lewis, Inscriptions on Tombstones and Monuments in Ceylon of Historical or Local interest (Government Printer: Colombo, 1913), v.
} 
that could be ephemeral. At any rate, there was a wave of such publications, some of them local, such as a survey of the old tombs of Surat by Augustus F. Bellasis (1861) and a manual of inscriptions in Salem by Le Fanu (1883). In 1880, the Governor of Madras, the Duke of Buckingham, ordered the production of facsimiles of tombstones in St. Mary's Church, Fort St. George. ${ }^{18}$

This gubernatorial interest reveals the colonial state's desire to create a useable past that historicised and legitimatised its existence. The ad hoc projects and private initiatives were expanded by an official project ordered by the Secretary of State for India in the 1890s. ${ }^{19}$ This seems to have been provoked by instructions on the format that the listings should be issued by the Government of India Home Department (Ecclesiastical) under the terms of Resolution no. 1/57, dated in Calcutta, 28 February 1893. The manner in which it was translated into action is revealed by the Rev. A. Führer, Archaeological Surveyor of the North-West Provinces and Oudh. ${ }^{20}$ The list was compiled from returns prepared by Divisional and District officers under instructions issued by Local Government in the Public Works Department resolution, dated at Naini Tal, 11 October 1893. In his preface, Führer waxed lyrical about the purpose of the exercise, which he inflated into virtually a manifesto for empire itself. It would 'preserve from unmerited oblivion... [the memory of] men who, at the sacrifice of their lives, have gradually raised the British Indian Empire to its present state of stability and eminence,' thereby 'ameliorating the conditions of its subjects, and embracing their spiritual and temporal happiness through the education of its people and the protection of their rights and liberties from the encroachments of invading and cruel enemies.' This listing would hence 'perpetuate, cherish and embalm their memory.' It was also designed for the education of the young (presumably European): 'Who will deny that the sight of a mere monument has not repeatedly inspired martial enthusiasm, the flame of patriotism or the emulation of genius in the youthful breast?' Führer's rhetoric may have been motivated by the particular conditions of the frontier area as well as by his professional sense of a high-flown spiritual mission, but it certainly elevated funerary inscriptions into the status of an imperial sermon.

Further examples of these compilations included C.R. Wilson's List of Inscriptions on Tombs and Monuments in Bengal possessing historical or archaeological interest. This declares that it was compiled by order of the Secretary of State for India in Council under

\footnotetext{
${ }^{18}$ Cotton suggested that only two copies of this survived in his day.

${ }^{19}$ Presumably the documents proposing and inaugurating this project are in the India Office Records, but it has not been possible to view them because of the coronavirus pandemic in 2020.

${ }^{20}$ Rev. A. Führer, List of Christian Tombs and Monuments of Archaeological or Historical Interest in the North-Western Frontier Provinces and Oudh (Allahabad: Government Printer, 1896).
} 
the direction of the Hon. Sir C.A. Elliott, Lieutenant Governor of Bengal and published by the Government Printer in Calcutta in 1896. It would be tedious to list them all in detail, but apart from Führer's already noted, others included Julius James Cotton's Inscriptions on Tombs and Monuments in Madras of 1905; Miles Irving's Inscriptions on Christian Tombs and Monuments in the Punjab, North-West Frontier Province, Kashmir and Afghanistan, volume 1, published by the Government Printer in Lahore in 1910, volume 2, 1912; E. A. H. Blunt's Inscriptions on Christian Tombs and Tablets in the United Provinces of Agra and Oudh published by the Government Printer in Allahabad in 1911; and J. Penry Lewis, Inscriptions on Tombs and Monuments in Ceylon. In many of these compilations, the ostensible authors were senior members of the Indian and Ceylon Civil Services, with much of the work compiled by local officials and brought together by assistants.

While the catalogues of epitaphs relating to Bengal have been noticed and analysed, little has been written about the Madras and Ceylon examples, nor about the way in which they reveal the 'four nations' dimensions and in particular the Scottish imperial deaths that they contain. ${ }^{21}$ These official compilations are a telling mixture of, on the one hand, homogeneity in the projection of professional hierarchy and virtuous character and, on the other, diversity in drawing attention to family and local origins back in Europe. Such sources are of course not without their limitations. This article will concentrate on the Cotton compilation for Madras and the Lewis for Ceylon, revealing the manner in which Scots were recorded and sometimes obituarised. In doing so it does not seek to exceptionalise Scots as a national group. Rather their memorialisation is used to tease out the subtle projection of the variations and differences as well as the commonalities that marked out the broader British and Irish colonial community. ${ }^{22}$

Advancing this analysis must however also involve acknowledging the problematic nature of the evidence. These compilations were selective and not comprehensive. While there are exceptionally large numbers of individuals listed in them, those who gathered the examples were in effect the arbiters of what was 'of historical interest' using contemporary criteria. From visits to these cemeteries, it is clear that there are other burials which on the face of it might be of equal interest to some of those included, at least from the point of view of the modern historian. Allowance has to be made, therefore, for a

\footnotetext{
${ }^{21}$ John M. MacKenzie, 'Irish, Scottish, Welsh and English worlds?' A four-nation approach to the history of the British empire," History Compass, 6 (2008), 1244-63.

${ }^{22}$ Angela McCarthy, "Ceylon: A Scottish colony?," in The Scottish Experience in Asia, c. 1700 to the Present. Settlers and sojourners, eds. T.M. Devine and Angela McCarthy (Edinburgh: Edinburgh University Press, 2017), 204-5.
} 
certain degree of social, professional, gender and other forms of discrimination in the examples selected. In other words, the directories also often reflect the obsession with status and professional significance so often characteristic of the nineteenth- and early twentieth-century British Empire in India. Yet, in spite of this health warning, these are remarkably useful directories.

\section{MADRAS}

Cotton's compilation was a major contribution to the official programme of recording inscriptions. ${ }^{23}$ It contains 2308 entries, the vast majority of them relating to deaths, but two or three to the provision of wells, a conspicuous form of charity that helped draw attention to the virtue and concern for local populations seen as so typical of the colonial elite. It was followed forty years later by a further publication to utilise the additional notes he compiled after the appearance of the first 1905 edition. ${ }^{24}$ In his introduction, Cotton suggested that it was essential to record the 'crumbling memorials of the European dead in India' to be found, in the words of Alfred Lyall, in the 'graveyards of exiles' in the 'Land of Regrets. ${ }^{25}$ More prosaically, but more practically than Führer's encomium, he averred that the history of old Madras is 'in no small measure written on its tombstones,' the relics of 'trueborn Englishmen of credit and renown.' Cotton's language reflects the heavily Anglo-centric framing of the Empire in Asia's origins and character. ${ }^{26}$ It is significant in this context that alongside celebrations of Anglo-Saxon expansion across the globe, he acknowledged that 'the Scotchman follows at a later stage in the race' (not much later as we now know). ${ }^{27} \mathrm{He}$ went on to indicate all the celebrated people, many of them relatives of significant literary figures, such as Sir Walter Scott or Charles Dickens, whose remains were scattered around the presidency. Notables included governors, missionaries, artists, surgeons, warriors, writers, civil servants, and various high-born persons, including Henry FitzClarence, illegitimate son of William IV. ${ }^{28} \mathrm{He}$

\footnotetext{
${ }^{23}$ Julian James Cotton, Inscriptions on Tombs or Monuments in Madras possessing historical or archaeological interest (Madras: Superintendent of the Government Press, 1905). Cotton (1869-1927) was a member of the Madras Indian Civil Service.

${ }^{24}$ Cotton's notes were purchased by the Government of Madras from the (surprisingly grasping) executors of his will in 1928. The second edition of the Inscriptions in two volumes included this extra material, edited by Rao Bahadur Dr. B.S. Baliga, Curator of the Madras Record Office and published by the Government Printer in 1945.

${ }^{25}$ Sir Alfred Lyall (1835-1911) reached the heights of ICS administration as Home Secretary and Foreign Secretary to the Government of India and Lieutenant Governor of the North-West Provinces. He was also a prolific writer and poet, publishing verses written in India in 1879.

${ }^{26}$ Marshall, "British society in India," 90-1.

${ }^{27}$ Cotton, Inscriptions, iv.

${ }^{28}$ Died in 1817 aged 22 and buried in Allahabad.
} 
also surveyed all the other Europeans who had been active in the area: Portuguese and Dutch before the British, as well as French, including Huguenots, and Danes, Armenians, and others. He noticed that the Dutch particularly had indulged in 'regal monuments' replete with elaborate heraldic devices and intriguing poems.

In a telling phrase, Cotton also argued that 'the literature of the tombstones may often be turned to capital account.' This presents a worthwhile motivation for the study of such texts. As I have argued elsewhere, the material on stones is capable of presenting documentary evidence not necessarily recorded in other media. ${ }^{29}$ At the very least, such inscriptions sometimes indicate social and familial contexts, professional status and affiliations, as well as revealing both attitudes towards the deceased and contemporary views of death. But in addition to the inscriptions, the annotations and additional material in the imperial listings can be tremendously valuable as sources on the colonial state's professional hierarchies, as well as on the social and geographical origins of its personnel. The compilers used local knowledge and newspapers to add significant amounts of information not otherwise available, as well as indicating access to now rare or lost sources. This is clearly informative in revealing lives (and, as we shall, see collectivities of lives) not necessarily prominently recorded elsewhere. Of particular value are the entries on women recounting lives and deaths in India (and below in Ceylon) which might otherwise have been little noticed.

In the case of Scots, there is an additional dimension, offering the particular flavour of Scots origins and life trajectories. Besides the way cultures of remembrance idealised sentiments of family, locality and religious faith, the example of Scots point to the cultural tactics used to symbolise enduring connections back to Europe. This was often done not by referencing the great imperial centres or using generic geographies such as Europe, England or even Scotland, but rather listing specific localities and places of origin. In this way diversity of place in the British and Irish Isles served to both confirm the deceased as a member of the colonial elite, while imparting a distinguishing and unique identity to the individual. Scottish backgrounds became a badge of differentiation at two distinct levels: They indicated the deceased's privileged position not just as a European but as a Briton, and so a member of the ruling order. Meanwhile explicit notification of a Scottish place of origin or family enabled the deceased to acquire a personal profile that helped them

\footnotetext{
${ }^{29}$ John M. MacKenzie, "Documents in stone: Records of lives and deaths of Scots abroad and in Scotland," in Death in the Diaspora, eds. Nicholas Evans and Angela McCarthy (Edinburgh: Edinburgh University Press, 2020), 176-200. In this, I focused on the extraordinary graveyard in Penang, Malaysia.
} 
stand out in the wider deathscape of regularised cemeteries. Scottishness denoted white privilege but also helpfully demarcated a person within that border group.

So far as the Madras compilation is concerned, the material covers over 80 cemeteries, churchyards and other places of interment, as well as tablets and memorials in major churches. The cemeteries and ecclesiastical graveyards include the important ones such as St. Mary's cemetery on the island in Madras (Chennai) which is now difficult of access because it has become so overgrown, St. Mary's church and compound in the fort, St. George's Cathedral, All Saints, Coonoor (although no Scots are recorded as buried at the latter, the author has seen and noted some), St. Stephen's and St. Thomas's in Undamagandalam (Ootacamund, Ooty), Salem and other towns in the mofussil (interior).

Using these records challenges the established understanding of when Scots began to appear in Asia under the Company's auspices. A reliance on the organisation's London based records, which usually provides only name and occupation details, can give the impression of marginal numbers before the 1720s. In this context the value added nature of deathscape records is they highlight genealogical and geographic details as well as the dates of an individual's time in Company's employment. ${ }^{30}$ Some of the early entries for the compound (that is the area around the church) of St. Mary's Church, Fort St. George, Madras, not only reflect the extent to which Scots were joining the Company military service at an early period, in some cases before the 1707 Union, but also indicates the fact that women were already joining them in India. The scale of infant mortality is of course apparent on many stones. One notable inscription there reads:

Here lies interr'd the body of Anne Seaton, wife to Francis Seaton, Capt. of the grenadiers of ye garrison, who having brought into ye world a daughter named Frances did herself in nine days after depart out of it, viz on the 16 May 1691, to the great regret of her surviving husband for the loss of so deserving a wife. With her lie also interr'd two of her children, a son and a daughter, viz Elihu and Frances who deceased 3 May 1691 and 7 May 1692. ${ }^{31}$

\footnotetext{
${ }^{30}$ Andrew Mackillop, "Locality, nation and empire: The Scots in Asia, c.1695-1813," in The Oxford History of the British Empire: Scotland and the British empire, eds. John M. MacKenzie and T.M. Devine (Oxford: Oxford University Press, 2011), 61-2.

${ }^{31}$ Cotton, Inscriptions on Tombs or Monuments in Madras, no. 33 (p.8). In January 2020, I visited and photographed many of these monuments myself. See figures on the following page.
} 
Although it is difficult to establish where Francis Seaton was born, there is no doubt at all that he was a descendant of a notable East Lothian family, son of Hannibal Seaton and Sibilla Pringle, grandson of Sir John Seaton, first baron of Barnes. The naming of a son after Elihu Yale, the Massachusetts-born governor of Madras, and having him act as godfather reveals how family units were key to the forms of British identity forged at the Empire's frontiers. Other early graves in St. Mary's include Captain Alexander Fullerton, born in Argyleshire (sic) in 1683, Captain of a Company of foot soldiers from 1709 until his death in 1726; also David Murray of Edinburgh, Chief Gunner of Fort St. George, died in 1732, aged 45. ${ }^{32}$ Gilbert Pasley, Surgeon-General of Madras, was born in Westerkirk parish in Dumfriesshire: his death at the age of 48 in 1781 is commemorated in this way: 'This stone will not want power to melt or virtue to amend the heart. It marks the grave of a common friend of mankind. It records the memory of the skilful physician Gilbert Pasley. ${ }^{33}$ It also commemorates what must have been a posthumous daughter who died in 1782 at the age of five months and four days. A central feature of these inscriptions was the intermixing of information on family (both in Europe and in Asia), professional standing and a clear record of public service. The memorialisation, at some length, of George Mackenzie illustrates these three points: the service in India, albeit in the government army, of a son of the Scottish aristocracy, the role of fellow officers in paying for such memorials, and the presence of a near relative who had joined his uncle in India. It reads:

Sacred to the remains of the Honorable George Mackenzie, second son of the late Earl of Cromarty, Lieutenant Colonel of His Majesty's $71^{\text {st }}$ Regiment, Colonel in His Majesty's Army, and Commander of the Forces at the Wallajabad station, who departed this life 4th June MDCCLXXXVII [1787] aged 46 yrs. In tribute to his much esteemed memory and great worth, the officers of the $71^{\text {st }}$ Regt, lamenting the loss of their gallant commander, and his nephew and nameson George MacKenzie, who has fought and bled by his side, have caused this monument to be erected. ${ }^{34}$

\footnotetext{
${ }^{32}$ Ibid, nos. 38 and 41 (pp.8 and 9).

${ }^{33}$ Ibid, no. 138 (p.26). Pasley had taken charge of his nephew, the 13-year-old later Sir John Malcolm when he had arrived in Madras as a cadet.

${ }^{34}$ Cotton, Inscriptions, no. 156 (p.28). 'Nameson' indicates that the nephew was named after him.
} 
The length of many of these memorial inscriptions (several much longer than this one) and the absence of abbreviations suggests either that such work could be commissioned relatively cheaply or that the Company was prepared to be extravagant in such commemorations. ${ }^{35}$

One family with a notable connection with Madras was the Brodies of Brodie Castle in Moray, now in the hands of the National Trust for Scotland. For example, James Brodie, who died in 1801, a member of the EIC's civil service, was drowned off Madras and was buried in St. Mary's Cemetery with the simple inscription, recorded in Cotton, as James Brodie, Esq., of the Honorable Company's Civil Service, on the Madras Establishment. One of his sons joined the Madras Cavalry and died there in 1826. Three of his daughters married locally, one to a Captain in the Madras Cavalry and two to civil servants. While the intergenerational nature of colonial service, not least in the EIC is widely understood, it is important to move beyond the masculine dimensions of such processes to appreciate the role of women in extending social and kin influence. ${ }^{36}$ Meanwhile, James's brother Alexander became a writer in Madras in 1773 and a junior merchant in 1782, buying the Burn estate in Kincardineshire on his return to Scotland. James built himself a fine house on the Adyar River in Madras, known as Brodie Castle after the Scottish ancestral home. ${ }^{37}$ It is a remarkable record of a Scottish family's connection with Madras, and an architectural expression of the genealogical and professional information duly recorded in Cotton. ${ }^{38}$

It is not always possible to identify with confidence the Scottish origins of wives, not least because of course Scots were far from endogamous. Indeed, marriage was a key way in which Scots in Asia became Britons. One example is Olympia Elizabeth Campbell, who died in 1794 and is commemorated in St. Mary's Church. ${ }^{39}$ She was the wife of then Captain, later General Sir Alexander Campbell of the $74^{\text {th }}$ Highland Regiment and came from Cornwall. Campbell (1760-1824, born in Perthshire) was granted a baronetcy after

\footnotetext{
${ }^{35}$ One of the longest was dedicated to the fifty-year career in India of the Danish missionary, the Rev. Frederick Christian Swartz, which was paid for by the East India Company in 1807, interestingly indicating the evangelical shift that took place in the Company at this time. Cotton, Inscriptions, no. 383 (pp.54-5). This was actually produced by the distinguished London sculptor John Bacon, junior (1777-1859). Swartz was also commemorated in the Swartz Church in Tanjore. Several others were erected by order of the Company and presumably paid for by it.

${ }^{36}$ Bernard S. Cohn, "Recruitment and training of British civil servants in India, 1600-1860," in Asian Bureaucratic Systems Emergent from the British Imperial Tradition, ed. Ralph Braibanti (Durham, NC: Duke University Press, 1966), 87-140; Margot Finn, 'Anglo-Indian lives in the later eighteenth and early nineteenth centuries," Journal for Eighteenth-Century Studies, 33, 1 (2010), 49-65.

${ }^{37}$ Brodie Castle is now part of the South India Conservatoire of Music. I visited it in early 2020 and, of course, it is a typical Georgian colonial house.

${ }^{38}$ Cotton, Inscriptions, no. 231 (p.38).

${ }^{39}$ Ibid, no. 193 (p.33).
} 
his exploits at the Battle of Talavera in the Peninsular War. Equally, however, these empire families illustrate the underappreciated ways in which the development of Britishness co-existed alongside the maintenance and even reinforcement of Scottish connections. Olympia's daughter, another Olympia, married Alexander Cockburn, a banker. ${ }^{40}$ Her second daughter married the celebrated Governor Sir John Malcolm, who was born at Burnfoot on the River Esk near Langholm. An interesting example of a wife of Scottish descent is Ann Anderson Young, the middle name indicating that her father was James Anderson, distinguished botanist and Physician-General of Madras. ${ }^{41}$ The inscriptions and memorials almost certainly indicate the manner in which diasporic Scots tended to socialise with and support each other in the manner hinted at in the inscription to Lieutenant Colonel George MacKenzie. Ann died in 1810, aged 33, 'relict of Charles Wallace Young, free-merchant, and daughter of Dr James Anderson, late PhysicianGeneral. Monument erected by Andrew Berry MD. ${ }^{42}$ Wallace was Young's cousin while Dr. Berry, Anderson's nephew, had been chief mourner at the funeral of Ann's father and had written his Latin epitaph. She was already a widow, her husband having died in November 1809, just a few months after her father. ${ }^{43}$ Anderson himself (1738-1809) was born at Hermiston, Midlothian, where his father Andrew Anderson was the local physician. Educated at Ratho School and Edinburgh University, he joined the EIC naval service in 1759 and moved to Madras in 1765. Cotton recorded that the bust and model of a magnifying glass formerly over the tomb in St. Mary's Compound had disappeared, but that the name Anderson appeared around the dome in Tamil, Telugu, Hindustani and English characters. Anderson had been particularly concerned with commercial plants, such as sugar cane, coffee, American cotton and European apple. He was an enthusiastic supporter of vaccination and had been interested in the introduction of silk production and cochineal to Madras. ${ }^{44}$ Anderson's monument in St. George's Cathedral is a seated statue by Sir Francis Chantrey, one of the most celebrate sculptors of the age, again with a Latin

\footnotetext{
${ }^{40}$ General Campbell returned to Madras as Commander in Chief and, after the death of his sons in the Peninsular War and at the Battle of Assaye in India, he arranged for his baronetcy to pass to his grandson, Alexander Cockburn, who changed his name to Cockburn-Campbell.

${ }^{41}$ Anthony Farrington, A Biographical Index of East India Company Maritime Service Officers, 1600-1834 (London: British Library, 1999), 17.

${ }^{42}$ Charles Wallace Young, who died at age 44, is to be found in: Cotton, Inscriptions, no. 1923, (p.330), where it is suggested that 'His manly generous and feeling mind fell a prey to melancholy occasioned by the very indifferent prospect of success in an agricultural speculation commenced in this province.' There seems to be a hint of suicide there.

${ }^{43}$ Cotton, Inscriptions, no. 267 (p.45). Her father's is at no. 261, (p.45).

${ }^{44}$ Anderson's entry in the Dictionary of National Biography.
} 
inscription in which he is described as 'Scoto Brittanus.' ${ }^{45}$ Not only does this category reflect the use of national labels in the Scottish universities, it provides a rare insight into the way hybrid identities were shaped by the highly distinctive nature of migration and service in the Asian half of the Empire. This is one of several magnificent monuments in both the Cathedral and St. Mary's Church in the Fort, Chennai. As elsewhere, these reflect the remarkable production of sculptures for India, most notably in London-a striking 'cultural traffic' between the metropole and the subcontinent. ${ }^{46}$

Another in St. George's portrays a fine sculpted figure of a highland soldier and commemorates 'Major-General Sir Robert Henry Dick, KCB KCH of Tullymet NB, one of heroes of Peninsula War. In HM's 42 ${ }^{\text {nd }}$ Regt Royal Highlanders, at Quatre Bras and Sobraon [he was killed at the latter]. Monument raised by the public of the Madras Presidency where he was Commander-in-Chief.' Cotton includes some biographical information to the effect that Dick had been born in India in 1785, repeating the story that Henry Dundas had been staying in Dunkeld with the Duke of Atholl and when out walking encountered a farmer's daughter who petitioned him to help her fiancé, a doctor who was too poor to marry her. Dundas got him the post of assistant surgeon in the EIC, enabling them (the parents of General Dick) to marry and go to India in 1781, where he made a fortune. Retiring in 1802, he bought an estate at Tullymet (now Tulliemet near Pitlochry) ${ }^{47}$ Given the prominence of Scots in military service, officers feature heavily in the memorials and monuments considered here. Another is dedicated to Lt Col. Thomas Maclean of the Madras Army, son of Alexander 13 ${ }^{\text {th }}$ Laird of Ardgour, 'late Resident at the Court of Travancore,' who died at Coimbatore in 1840, aged 58 after 'a long and painful illness.' Erected by his children with a lengthy and admiring inscription, including the fact that he had an uninterrupted residence in India of more than 37 years. The way Maclean was remembered encapsulates how monuments and inscriptions blended the conventional emphasis on dedicated service, professional role with referral back to the deceased's place of origin. Although buried in Ooty with his wife of 30 years, this monument in St. George's Cathedral, depicting a Travancore palm with a St. Andrew's

\footnotetext{
45 There is no indication of the Christian denomination of which Anderson was an adherent and, at the time of his death, St. Andrew's Presbyterian Church (and associated graveyard) had not yet been founded (built 1818-1821). As a high-ranking official, he almost certainly attended St. Mary's in the Fort (opened in 1680). St. George's was not built until 1815 , indicating the time it took to commission Chantrey, export the statue and decide on the most appropriate place to display it.

46 This trade is examined in: John M. MacKenzie, A Cultural History of the British Empire, chapter on 'Statuary and Sculpture,' forthcoming in 2022.

${ }^{47}$ Cotton, Inscriptions, no. 419 (p.78).
} 


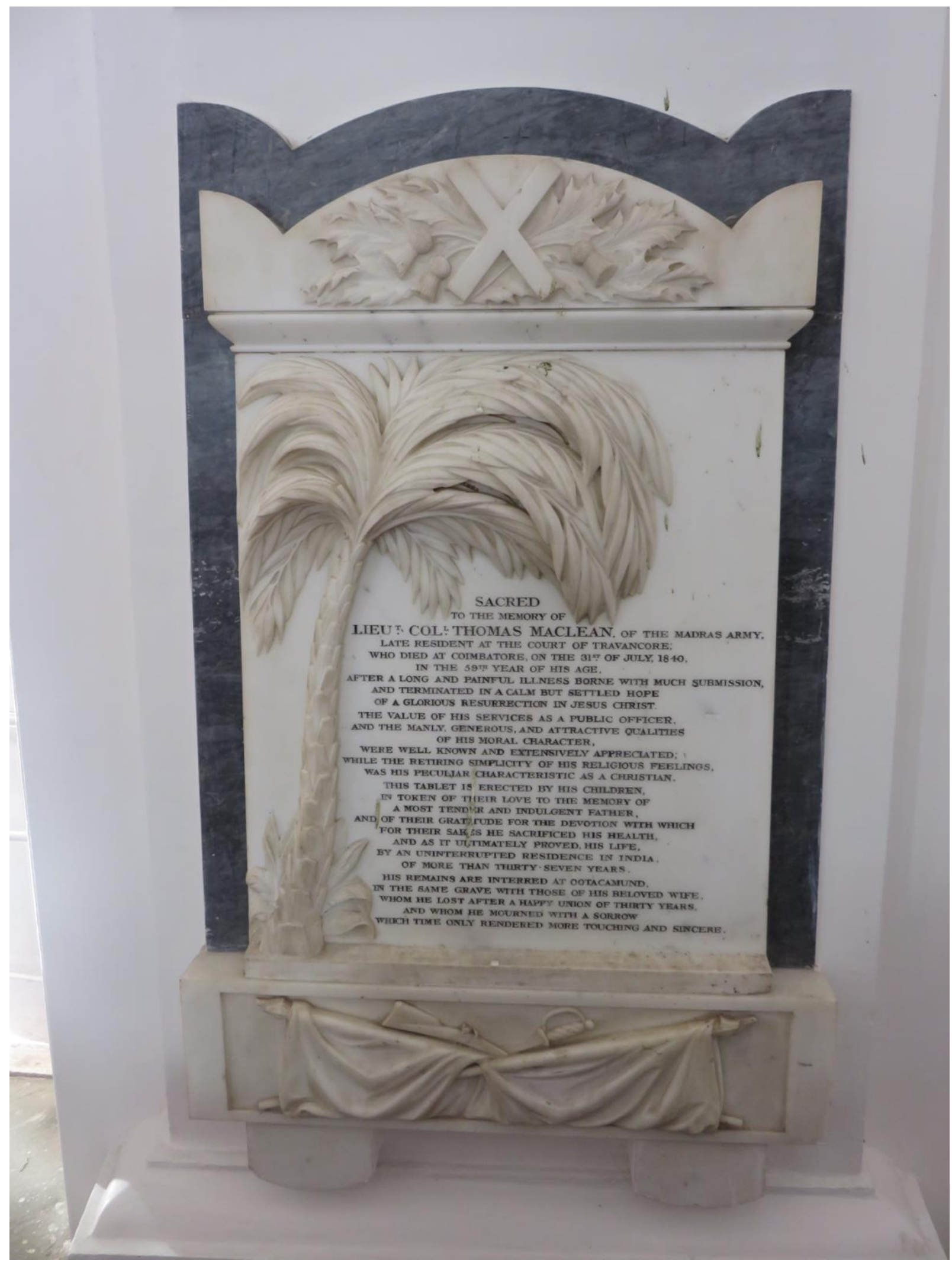

Fig. 1. Memorial to Lt. Col. Thomas Maclean in St. George's Cathedral, Chennai. Note the St. Andrew's Cross as an identifier. Taken by the author. 
cross and thistles above, was sculpted by the firm of Denman in London's Regent Street. ${ }^{48}$ St. Mary's contains a fine monument consisting of a relief of a light cavalry officer contemplating a column marked 'Rangoon, Pegu' by the distinguished sculptor Edward Richardson (1812-1869) and is dedicated to Malcolm McNeill, Colonel in the Madras Light Cavalry, who died in Rangoon aged 52 from 'coup de soleil' [presumably sunstroke] while commanding $2^{\text {nd }}$ Brigade Madras troops at the capture of Pegu. Esteem was indicated by the fact the memorial was 'erected by friends and fellow officers.' ${ }^{49} \mathrm{McNeill}$, born 1800, was from a 'well-to-do' family in Argyllshire, was educated in Edinburgh and joined the Madras Cavalry in 1819.

It is not always possible to be sure that a commemorated death is of a Scot, although it may seem highly likely. Examples of a commemoration of someone who was not a military officer or a member of the civil service, or a wife of same are relatively rare. One such is of Samuel Graham, who died in 1872, aged 52 and was described as 'respected coachman of six successive governors of Madras over a period of nearly 20 years.' He died at the remount depot at Hosur, was buried at Matagiri in the Salem district, and the stone was erected by 'his affectionate sister' Margaret McKie. ${ }^{50}$

A very interesting category of commemorations from personal records involves memorialisation of people who had served in India but had died in Scotland. This placing of people in two different locales - physical burial in Scotland and a monument in South Asia - blurred boundaries and spaces, connecting seemingly disconnected parts of the world. Individuals often received admiring encomia on memorials erected by former colleagues who clearly wished to record, sometimes in some detail, their service in India. Examples include several ministers of St. Andrew's Church in Madras: Rev. Robert Kerr Hamilton who served as senior chaplain in Madras, 1840-1858 and died in Edinburgh in 1865; Rev. Chalmer Raitt Dunhill who served in the same church and was interred at Athelstaneford (East Lothian) in 1896: and the influential Rev. James Neill Ogilvie, who served in Madras 1885-1905, was later Moderator of the Church of Scotland and chaired various missionary committees, dying in Edinburgh in 1926. There is also a sculptural bust and a hugely admiring memorial to John Wylie, physician general in the Presidency of Madras, who died near Dollar in 1852. Indeed, the highly impressive St. Andrew's in Madras is inevitably packed with memorials of Scots who died in India, some of them buried in the kirkyard outside. Elsewhere in the Presidency, there is an impressive obelisk

\footnotetext{
${ }^{48} \mathrm{Ibid}$, no. 412, (p.74). The death of his wife Eliza in 1836 is recorded at no. 406 (p.74).

${ }^{49}$ Ibid, no. 364 (p.65).

${ }^{50}$ Ibid, no. 1672 (p.289).
} 
and memorial at St. Thomas's Church, Ootacamund to the Governor William Patrick Adam of Blair Adam in Scotland who died in office in 1881. This one was erected by Order of the Government. The fact that it is not associated with the main Anglican Church, St. Stephen's, is interesting and may reflect Adam's tendency towards evangelicalism. ${ }^{51}$

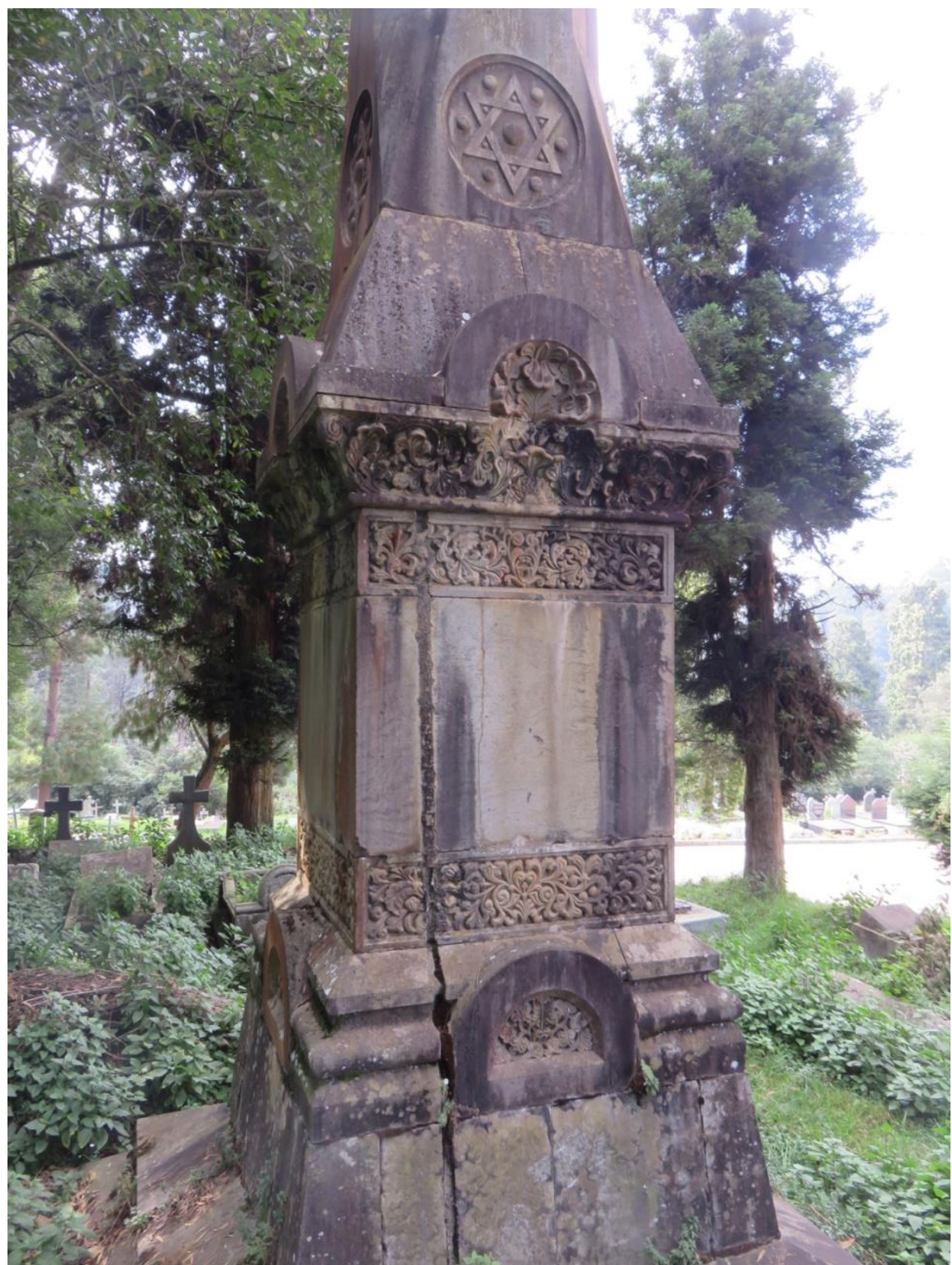

Fig. 2. Obelisk to Gov. William Patrick Adam, St. Thomas's Church, Ootacamund. Taken by the author.

\footnotetext{
${ }^{51}$ Sidney Lee (revised by H. C. G. Matthew), “Adam, William Patrick (1823-1881)," Oxford Dictionary of National Biography: https://doi.org/10.1093/ref:odnb/109 [Accessed: 17 Oct. 2021].
} 


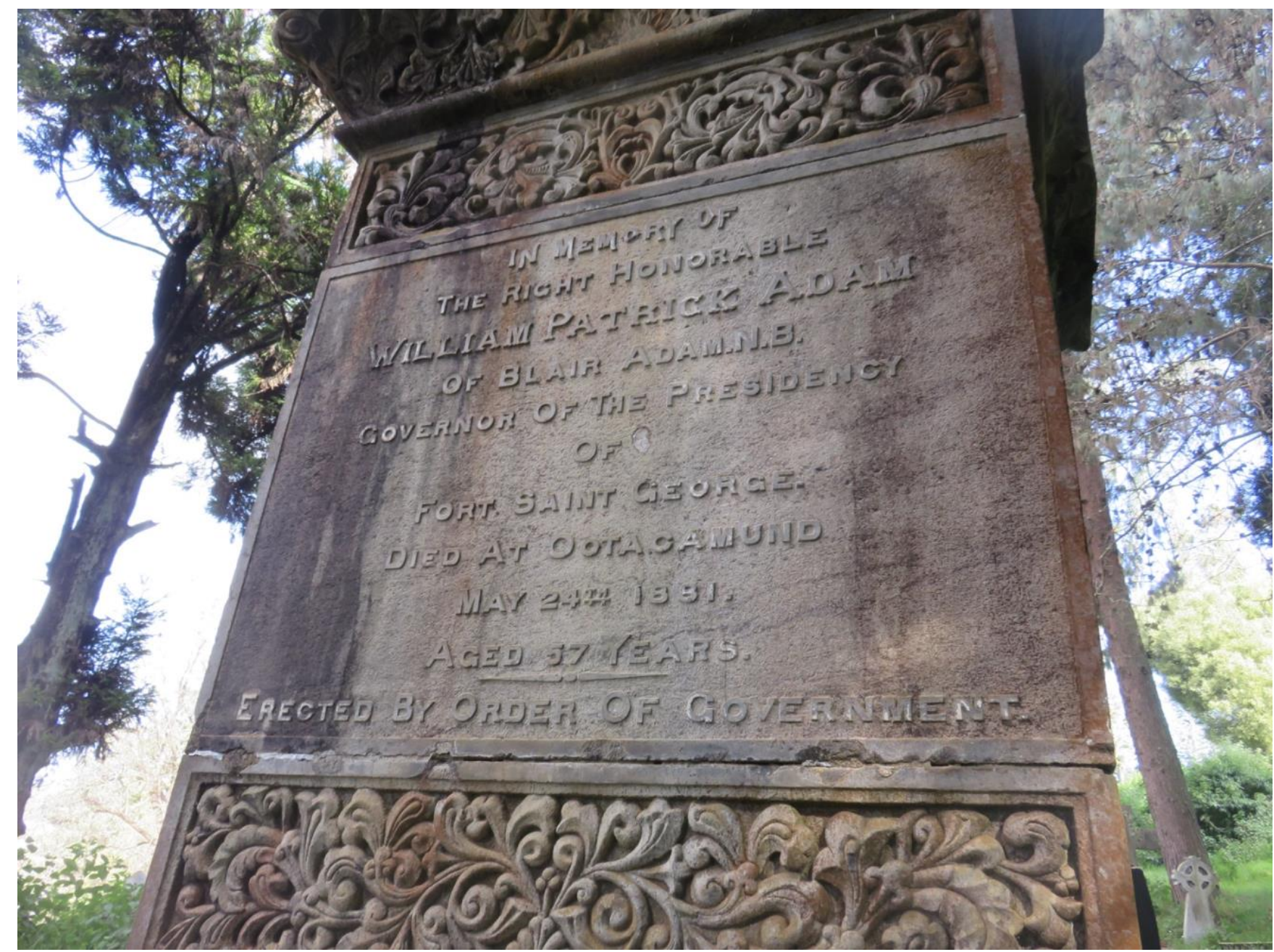

Fig. 3. Memorial to Gov. William Patrick Adam, St. Thomas's Church, Ootacamund. Taken by the author.

Monuments to significant events in India repay some deconstruction. The monument commemorating the Battle of Seringapatam in the modern Srirangapatna, Mysore lists the regiments (including Scottish ones) involved in the siege and many of the officers who died down to the lowest commissioned rank of ensign. But as in Britain ordinary soldiers tend not to be commemorated until the twentieth century. Such a listing can also be found among the names on the Kashmir Gate and the Mutiny Memorial in Delhi, both including many Scots. Bailey's (or more properly Baillie's) Dungeon in the fort at Srirangapatna retains the name of Colonel William Baillie from Inverness-shire who died there in 1782 when imprisoned by Tipu Sultan. A memorial there was erected by his nephew John 
Baillie in $1816 .^{52}$ These examples demonstrate that while Cotton's listing is hugely valuable, fieldwork reveals that any examination of some of the sites of commemoration in memorials, churches and graveyards unveils additional material, of which the examples here only scratch the surface.

\section{Ceylon}

John Penry Lewis's List of Inscriptions on Tombstones and Monuments in Ceylon of Local or Historical Interest, printed by H.C. Cottle, Government Printer, Colombo and published in 1913 contains inscriptions from twenty-two locations on the Indian Ocean Island, most notably in Colombo, Trincomalee, Jaffna, Kandy and the hill station of Nuwara Eliya. Ceylon of course had a different historical trajectory from India. The coastal regions were first acquired from the Dutch in 1796, confirmed in 1815, and Ceylon remained a Crown Colony until independence in 1948. The inland Kandyan kingdom was conquered in 1815, and the British consolidated their position in the entire island by 1818 following the suppression of rebellion. Plantations of coffee, cinchona and above all tea became key elements of the economy, and the colony constituted a significant zone of Scottish settlement, particularly as the tea industry was largely developed by Scots. ${ }^{53}$ Another connection with Scotland was that, similarly to the former Dutch territory of the Cape, Scots became significant in administration of the law since their legal system had affinities with Roman Dutch law rather than English common law. ${ }^{54}$ As a result of these settlement patterns, it is possible to find examples of group or chain migration from particular places in Scotland, as will be seen below.

A Scot who played a significant role in the early years of British conquest was Alexander Cadell, born in Carron Park, Stirlingshire in 1781. Appointed a writer in the colony in 1801, he was the Collector of Colombo in 1804, Collector of Jaffna in 1805 and Civil and Military Paymaster General from 1806 until his death in 1821. His memorial in St. Peter's Church in the Fort was erected by his brothers ${ }^{55}$ Highlighting familial links served several functions. The deceased's character was shown to be such that he warranted

\footnotetext{
${ }^{52}$ For the Baillie family in India, see: Alexander Charles Baillie, Call of Empire: From the Highlands to Hindostan (Montreal: McGill-Queen's University Press, 2017).

${ }^{53}$ Angela McCarthy and T.M. Devine, Tea and Empire: James Taylor in Victorian Ceylon (Manchester: Manchester University Press, 2017). To this day, many of the plantations have Scottish names. See also: D.M. Forrest, A Hundred Years of Ceylon Tea, 1867-1967 (London: Chatto \& Windus, 1967).

${ }^{54}$ D. L. Carey Miller, "Three of a kind: Positive prescription in Sri Lanka, South Africa and Scotland," Stellenbosch Law Review 19, 2 (2008), 209-230.

${ }^{55}$ Lewis, Inscriptions, no. 8 (p. 9) and 70A, (p.32).
} 
public affection. More symbolically, the reconnection with his brothers collapsed the distance between Ceylon and Scotland, incorporating Cadell back into a geography of belonging that reduced the alien and 'othered' nature of his final resting place. He was also commemorated on a granite obelisk on his grave in Galle Face burial ground which reads in a sentimental twist that 'He was preparing to return to his native Country when attacked by the illness from which he died, February $5^{\text {th }}, 1821 .{ }^{56} \mathrm{He}$ died of a liver complaint and seems indeed to have enjoyed high living, particularly in respect of lavishly entertaining visiting dignitaries.

The example of chain migration is unveiled through a grave inscription in the Old Garrison Cemetery, Kandy which commemorate the brothers, James and Francis Blacklaw, who died in May and October 1863, aged respectively 40 and 31. Their deaths prompted Lewis's annotations relating the story of a Laurencekirk migrant network. Another brother, Hugh survived as a long-established planter on the Harmony Estate and left the island in 1907. In the Times of Ceylon in 1904 Hugh wrote that Peter Moir, who came from the same place as himself, had come to Ceylon in 1843 to manage Mr Hadden's properties,

and enticed a lot of young people from our small town to come out here. It was through his influence that my brothers and I came to Ceylon. It is a very small town ours, St Laurencekirk, Kincardineshire, with a population of about 2000 souls, yet at one time there were as many as fourteen St Laurencekirk men in Ceylon. There were my four brothers and I, the four Moirs, James Taylor of Golconda, pioneer of tea and cinchona, Robertson, father of Robertson of the GPO, Petrie, the two Bissets, and Stiven of Ancoombra, Matale West, who afterwards went to Kandenuwara and died at the Galle Face Hotel in 1868. Of my four brothers, James, who was in Kotmalee, died in 1863, Alexander went out coffee planting in Brazil and died at Rio de Janeiro about four years ago. Charles was long in Ceylon and I don't know where he is now. I arrived in Ceylon on 23 ${ }^{\text {rd }}$ August 1858 in the good ship Briton, a sailer [sailing ship] which came round the Cape, and did the voyage in three months - just 120 days. She was a little ship of but 350 tons ... Colombo was just a one-horse show sort of place.... ${ }^{57}$

\footnotetext{
${ }^{56}$ Ibid.

${ }^{57}$ Ibid, no. 1176, (p.313). The Old Garrison Cemetery in Kandy was opened in 1824.
} 
The different levels of family memory and highly localised chain and step migration to a transhemispheric range of destinations revealed by Hugh Blacklaw's testimony underline how methodologies derived from deathscape evidence can facilitate microglobal histories. While James Taylor came from Auchenblae, up the road from Laurencekirk, the fact is that the Old Garrison Cemetery was simply full of Scots, revelatory of the number who became estate managers, sometimes at a remarkably young age. There is also evidence of the manner in which these Scots formed an ethnic community. Examples of these are worth noting in detail as they exhibit the characteristic combination of age, profession and explicit listing of place of origin in Scotland. Typical are those included in the Appendix to this article.

Such is the detail in such inscriptions that they provide glimpses into the recreational and leisure activities of the resident Europeans. If Thomas McCall was drowned in a river accident, others seem to have found the allure of the lake in Kandy sufficiently irresistible to cause further deaths. For example, Robert Hamilton Sinclair, born in Kenmore, Perthshire in 1853, was drowned in the lake in 1886. Sinclair had been in the Ceylon Civil Service from 1874 until his death, most recently as the police magistrate in Kandy. He had just been appointed second assistant to the colonial secretary of the colony, had been out walking with Captain Fraser and they had decided to swim to the island in the lake. Fraser was rescued in an exhausted state, but when a party of Argyll and Sutherland Highlanders went out on a boat to try to find Sinclair's body, Drummer Alfred Mathieson fell overboard and was in turn drowned. These accidents are commemorated in the Mahayaya Cemetery in Kandy, which is also the location of the burial of James Taylor of the Loolecondera estate, who died in 1892 at the age of 57. The gravestone describes him as 'pioneer of the tea and cinchona enterprises in this island', the stone erected 'by his sister and many friends in Ceylon. ${ }^{58}$

Other types of accidents reveal that Scots in Ceylon conformed to the strong association between colonial masculinity and hunting, and that they maintained the large suit of servants that so marked out social and domestic life in such empire destinations. It is precisely the prosaic, incidental nature of the information which makes it so useful. Archibald Montgomerie from Ayr, an ensign in the $45^{\text {th }}$ regiment, went out shooting elephants almost every day and died of jungle fever [malaria?] at the age of 19 in 1821, buried in the Old Garrison Cemetery. John Spottiswoode Robertson, born in Edinburgh in 1823 , a sergeant in the $73^{\text {rd }}$ regiment (and son of one of the deputy keepers of the records

\footnotetext{
${ }^{58}$ Ibid, nos. 1246. 1247 and 1256 (pp.332-33). The Mahayaya Cemetery was opened in 1840.
} 
of Scotland) was killed by an elephant on a shooting trip in $1856 .{ }^{59}$ One stone commemorating a young man, no more than 20 years old, speaks for itself;

This stone has been placed here by certain members of the Public Service in memory of a noble action wrought in the year 1868 by James Gordon of the Public Works Department who, being wounded to death by the accidental discharge of his gun, thought less of himself and his pain than of the safety of the servants who were with him, and lest suspicion of foul play should attach to them, devoted the remnant of his fast failing strength to the task of recording in his note book, the exact nature of his accident.

He was buried at St. Andrew's Church, near Anuradhapura. ${ }^{60}$

A pioneer of the Dimbula tea region William Smith of the Mattukelley estate died in 1896 at the age of 69 and is buried in the Lindula churchyard near Nuwara Eliya. He seems to have been one of the losers in the plantations business since it is said that 'he lost all in the end and his heart was broken.' He seems to have been quite a character with a penchant for hunting with hounds, since an article in the Times of Ceylon Christmas number 1909 revealed that in 1869 he was living at Craigie Lea, opening Drayton [estate], with ' 32 of the best hunting dogs that ever came to Ceylon.' He opened Mattukelly estate in 1865 . He was a very hospitable man but fearful to argue with - he always insisted he was right, even when losing the argument, saying in 'broad Scotch': 'Young man! You will allow me to know best!' 'The failure of coffee and cinchona broke him but not his spirit. ${ }^{61}$ The psychological toil of long-distance sojourning, already noted in the case of the possible suicide of Charles Wallace Young, was clearly prevalent enough to warrant routine but euphemistic acknowledgement. Another indication of the stresses that some planters suffered comes in the case of George Sloan Paxton, the son of John Paxton, a doctor in Kilmarnock, Ayrshire. George died in 1900 and is also buried at the Lindula Churchyard. He seems to have moved not only among several plantations, but also across continents: 'for some years under the Leechmans [owners?] at Kadugannawa, and then on Hunukotuwa, Kotmale, which he left in 1887 for Brazil, his health having become affected

\footnotetext{
${ }^{59}$ Ibid, no. 1150 (p.309). The annotation indicates that in 1833 Private James Buchanan of the $78^{\text {th }}$ Highlanders had been killed by an elephant near Nuwara Eliya.

${ }^{60}$ No. 1066, (p.288). I can find no modern record of this St. Andrew's Church.

${ }^{61} \mathrm{Ibid}$, no. 1464, (p.375). From other entries it is apparent that hunting with hounds was one of the principal pastimes of planters in Ceylon.
} 
mentally.' Returning to Ceylon 1895, his health broke down again while in charge of Tientsin. Latterly he was on Waltrim and Kowlahena. ${ }^{62}$

It is possible to identify many more Scots in the listings of inscriptions in Lewis. The number of those who are can be positively identified as Scots amount to 201 men. ${ }^{63}$ The number of women married to Scots (possibly Scottish themselves, but not necessarily so) comes to 31 , making a total of 232 . These are however very slippery figures since there may well be other men who were Scots, but not identifiable as such, while the marital figures may conceal non-Scottish women since the birthplace of females is seldom identified. On the other hand, there may be other Scottish women married to non-Scots, but impossible to distinguish them. Moreover, as we have seen in the case of Cotton, the transcriptions are selective and those compiling them only passed on those that were deemed to be of 'historical or local interest'.

Angela McCarthy has rightly stressed the importance of fieldwork in supplementing these lists and to that end has examined the commemoration of Scots in the tea-growing areas of upland Ceylon. She has also reported a preliminary statistical analysis of the numbers that mention ethnic origin in the Garrison Cemetery in Kandy. ${ }^{64}$ While there are some notable examples of such references, for example in Holy Trinity Church, Nuwara Eliya (including Archibald McPhee McNeill, 1883-1949, who is proclaimed as originating from the island of Colonsay in the Inner Hebrides), it is alleged that comparatively few seem to mention Scottish origins (nevertheless, the list above indicates the number that can be identified as Scots). This may, however, be because of the high proportion of Scots among the British residents of Ceylon, perhaps as high as $25 \%$, much higher than the $10 \%$ that Scotland constituted in the British population. Thus, it was simply almost normal to have Scottish origins in this context and therefore largely unremarkable. Ceylon has sometimes been described as a 'Scots colony' and plantation and other place names, particularly in the hills, reflects this. ${ }^{65}$ Plantation names include Glasgow, Edinburgh, Culloden, Invergordon and Logie. Scotland seemed to be everywhere, although it is true that Holy Trinity was established as an Anglican Church in 1843 and burials and memorials associated with it may have been rather inhibited from referring to Scotland. It is also perhaps possible to speculate that the term 'North Britain' is more likely to appear in such contexts and was also used by Scottish Episcopalians.

\footnotetext{
${ }^{62}$ Ibid, no. 1469, (p.376).

${ }^{63}$ I am indebted to Dr. Nigel Dalziel for statistics and other research support.

${ }^{64}$ See also: Angela McCarthy, "Scottish headstones in Ceylon in comparative perspective," in Death in the Diaspora, eds. Evans and McCarthy, 108-126, esp., 116.

${ }^{65}$ McCarthy, "Ceylon: A Scottish colony?," 204-5.
} 
Moreover, as we have seen in Madras, the existence of Scottish churches and separate graveyards ensured that places of birth were more likely to be mentioned. This is certainly true of St. Andrew's Kirk in Colombo, which was opened in 1842, where a large number of memorials commemorate Scots. The pattern by which burial in a specifically Scots Kirk increased the likelihood of noting an individuals' place of origin underlines how these religious establishments and associated cemeteries acted as ethnic anchors, sustaining a sense of Scottishness among Ceylon's colonial population. Before the existence of this church, Scots were often buried and commemorated at the Dutch Protestant church in Colombo. An example was George Hay Boyd from Crimond in Aberdeenshire, a merchant in Ceylon, who died in 1838. A later example is a commemoration of 'William McIntosh of Dundee, Scotland, Manager India Jute Co. Mills, Serampore, nr Calcutta, who died at Galle 8 Aug 1873 aged 35 years.' It is clear that some Scots preferred the Dutch Calvinist Church to St. Andrew's, perhaps simply for geographical reasons, since the Dutch church was in a different quarter of the capital. In

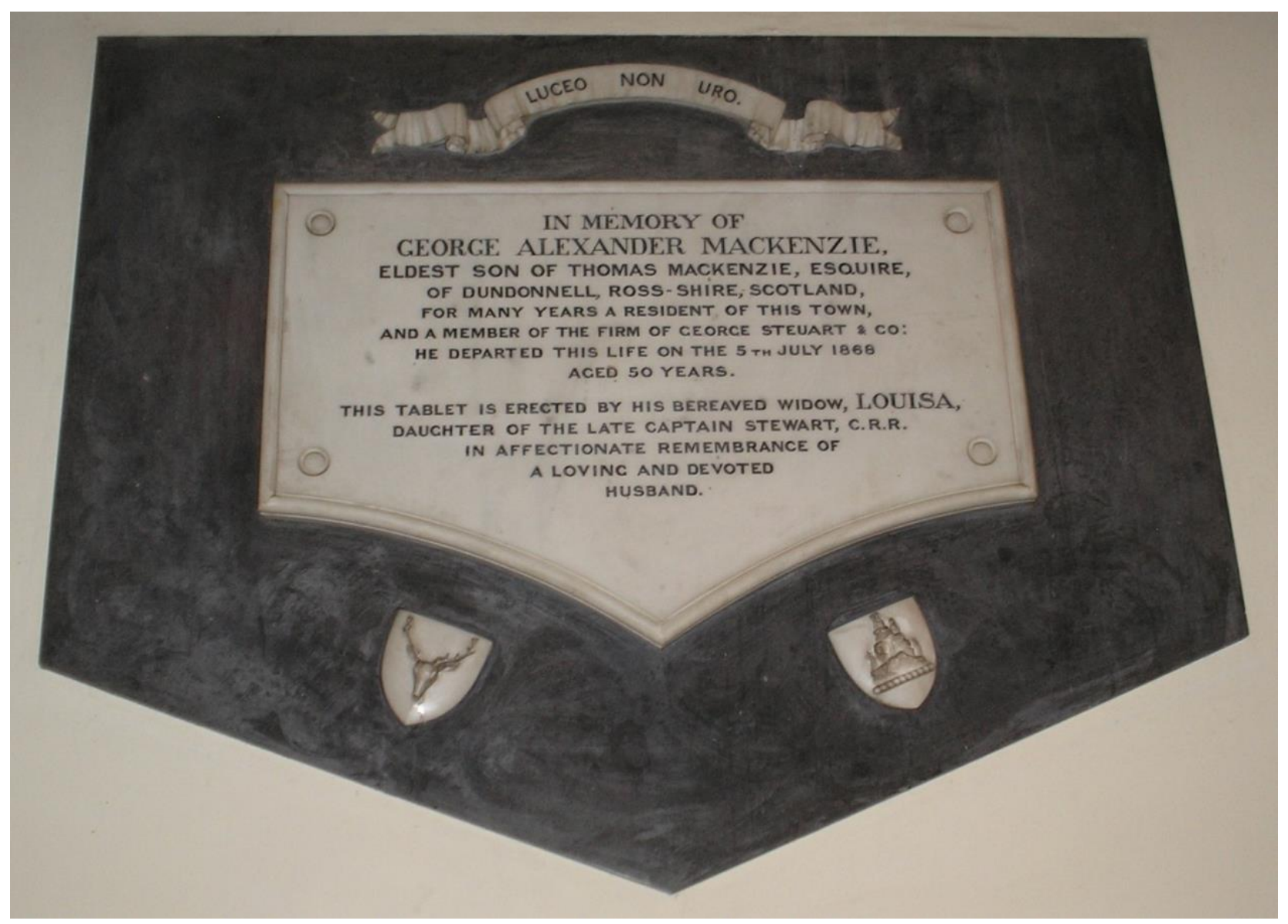

Fig. 4. Example of a memorial to a Scotsman in Sri Lanka: Memorial to George Alexander MacKenzie at Anglican Christ Church, Galle Face, Colombo. Taken by the author. 
the twentieth century, residents continued to memorialise a notable figure who had died in Scotland, although at a young age. This is in honour of 'Donald S. Ferguson, Editor of the "Ceylon Observer" who died at Elgin, Scotland, 23 July 1911 aged 33 years, erected by the journalists of Colombo who knew him and loved him for his many qualities of heart and mind. ${ }^{66}$

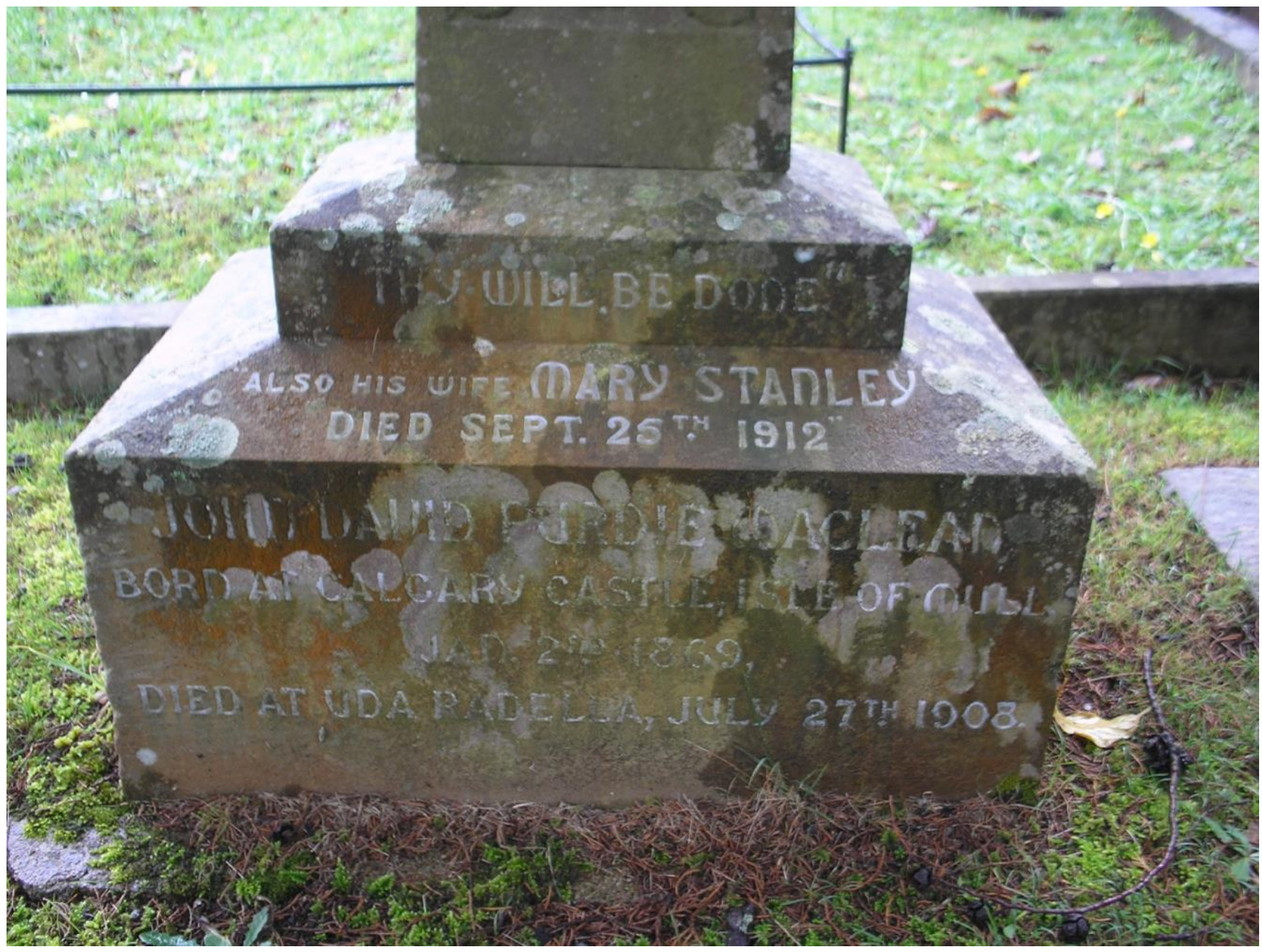

Fig. 5. Example of a memorial to a Scotsman in Sri Lanka: Memorial to John David Purdie Maclean at the All Saints Church, Nuwara Eliya, who was born at Calgary Castle, Mull, Inner Hebrides, Scotland. Taken by the author.

\section{Conclusion}

This article has examined the manner in which Scots were commemorated in two of the collections of commemorative material, those of Cotton for Madras and of Lewis for

${ }^{66}$ These examples come from the authors's field work. 
Ceylon. It has also included additional material from the presidency of Madras, from hill stations and from Ceylon (Sri Lanka) which is either not included in these listings or is mentioned only in abbreviated form. It is however clear that the remarkable examples of the catalogues of memorialisations by Cotton and Lewis, so typical of the imperial passion for recording and maintenance of data, constitute a valuable research tool which, through the inscriptions themselves and from the annotations of the authors from sources not readily available, unveil significant details about social life, ethnic affiliations, and disease, as well as sporting and other activities of Scots in Ceylon and Madras. They also reveal some of the predilections and prejudices of those who compiled them. But they additionally need to be supplemented by fieldwork, by visits to the graves and churches where more information can be gleaned. Extra information can be secured from architectural contexts, from the quality of stonework and sculpture of such materials, from the inclusion of symbols, as well as from some inscriptions not included in the listings. The compilations therefore offer valuable pointers, but primary research remains key.

It can additionally be suggested that this discourse of Scottish Deathscape adds a further dimension and in some respects a modest qualification to the contentions of Joseph Sramek regarding the intersection of themes of religion and nation in colonial South Asia. ${ }^{67}$ There can be no doubt that long-standing ethnic divisions are sometimes apparent in these commemorations of death and that the British Empire often 'accentuated rather than dissolved' these differences. Sramek is clearly right that we need to step outside the boundaries of Britain to examine the significant perpetuation of such ethnic distinctions. How this process of ongoing demarcation and distinctiveness interacted with the common identities shared with their fellow English, Welsh and Irish sojourners, be these around ideals of British, European or racial allegiance, are much better understood for the colonies of settlement. The Indian Ocean World provides an expansive, hugely complex and variable framework that remains noticeably understudied by comparison. Scots are invariably (but not always) identified as such and the qualities of the deceased are sometimes emphasised as reflecting such origins, while there is clear evidence of the activities of Scottish communities in organising monuments and their inscriptions. In these ways, fellow Scots sought to mark out the achievements of their compatriots. However, while it is true that many of these commemorations are inevitably found in Scottish churches or graveyards in India and Ceylon, it can also be noted that the endeavours of both military and civilian lives and deaths were depicted as taking place

${ }^{67}$ Joseph Sramek, "Rethinking Britishness: Religion and debates about the "nation" among Britons in Company India, 1813-1857," Journal of British Studies, 54, 4 (2015), 822-43. 
within the objectives of the British imperial mission. Nevertheless, the emphasis on ethnic distinctions continues right up to the end of British rule, illustrating the manner in which imperial enterprise was located within the contexts of the four nations. To a certain extent, this reflects the desire of Scots to stress their right to equality of treatment in both religious and secular fields, while emphasising the projection of the British Empire as a zone of joint enterprise. ${ }^{6}$ We should, however, also note cultural contexts. These include not just the churches built in the East India Company period in India (and a little later in Ceylon) and the separate graveyards sometimes associated with them, but also the Caledonian societies and social and sporting events organised by them such as Burns nights, St. Andrew's Day dinners and in some places Highland Games. Together, all of these distinctive cultural affiliations (though of course not all Scots participated in them) maintained a tradition of separate ethnic identity. To some extent at any rate, such separate origins were frequently re-emphasised in death.

${ }^{68}$ MacKenzie, "Irish, Scottish, Welsh and English worlds?," 1244-63. 


\section{ApPendix: Scots Listed in John Penry Lewis's List of InsCRiptions on TombStones AND MonUmENTS IN CEYLON OF LoCAL OR HiSTORICAL INTEREST (Columbo: Cottle, 1913)}

George Baxter Wilson of Aberdeenshire, superintendent Galaha estate, died of remittent fever, 1865, aged 20

Walter Ross Duff of Edderton, Rossshire, died 1865, aged 32

James Urquhart of Marytown died of cholera in 1865, monument 'erected by proprietors of Hantane Estate in appreciation of his zeal in their interests while managing that property'.

Donald Bain of Kingussie, Invernessshire, died 1866, 'a true Highlander, sincere friend, much regretted by all who knew him'.

Frederick Wernham of Banffshire, died 1871, aged 38, Troop Estate, Dimbula, erected by his widow.

Thomas Denrochie McCall of Hamilton, who drowned in 1872 when his canoe capsized in the River Bogawantalawa-ova when in spate, aged 24, 'erected by his fellow planters in Hewahette who had learned to love him well and those in Ceylon who had known him at home'.

James Gibson, son of a merchant in Pitlochry, who died at Kandy aged 26 in 1873.

Robert Arnott of Inverness who died at the Midlothian Estate, Maskeliva, aged 33 in 1875 and was interred on the estate, though commemorated in the cemetery. ${ }^{69}$

${ }^{69}$ The eight Scots listed here are in Lewis, Inscriptions, nos. 1179, 1180, 1184, 1186, 1197, 1199, 1201, 1208, (pp.318-19). 